\title{
Effect of Risk- Based Audit on Financial Perfomance: A Survey of Insurance Companies in Nakuru Town, Kenya
}

\author{
${ }^{1}$ Francis K. Kirogo, Mr. Solomon Ngahu, Mr. Juma Wagoki \\ JKUAT, Department of Business Administration, P.O Box 7182 -20100 Nakuru, Kenya \\ Lecturer, JKUAT, Department of Business Administration \\ , Lecturer, JKUAT Department of Business Administration,
}

\begin{abstract}
The purpose of the current study was to establish the effect of risk assessment on financial performance in insurance firms in Nakuru town. Descriptive survey was employed. The target population comprised of 52 management employees in 27 insurance firms in Nakuru town. Census was employed to elect the sample size in the study. Data was collected using a structured questionnaire with questions on a 5-point Likert scale. Data was analyzed using mean, standard deviation, percentage and Pearson correlation analysis and the results presented in tables. The Statistical Package of Social Sciences software was used to assist in data analysis. The study concludes that risk based auditing through risk assessment positively affected the financial performance of insurance companies in Nakuru Town. Risk assessment enables the insurance companies to detect risks on time and concentrate on high risk areas leading to increased transparency and accountability and enhanced financial performance of insurance companies. Thus the study has found a strong association between risk based auditing and financial performance of insurance companies. The study recommends that management of insurance companies in Nakuru Town should adopt effective risk based audit practices such as risk assessment to enhance effective and efficient financial performance. The findings of this study are expected to provide useful insights and fresh empirical evidence of the relationship between risk based audit practices and financial performance in insurance companies in the Kenyan context.
\end{abstract}

Key words: Risk Based Audit, Risk Assessment, Risk Controls, Risk, financial performance, insurance companies

\section{Introduction}

It is asserted that risk-based auditing focuses upon the analysis and management of risks. According to Beekes and Brown (2006) risk-based audit involves risk management and internal control systems. Kasiva (2012) as cited in Sarens and de Beelde (2006) noted that it is not clear to what extent different levels of focus on risk based audit influences directly or indirectly an organization's risk management and internal control practices. However, Covey (2004) has observed that in today's dynamic and rapidly evolving workplace and globalized economy, organizational performance is said to be associated with the development of personal performance, skills, knowledge and experience. Against this backdrop, the scholar is of the view that the ability to achieve and maintain high performance and productivity in organizations is a key challenge that management faces today. Cohen (2008) adds that organizations that object at enhancing productivity with rigorous planned strategies, staff with balanced and mixed thinking and how it approaches problem solving, can better address the situational uniqueness of projects and conquer the challenges of contemporary projects.

Goodwin-Stewart and Kent (2006) assert that internal auditing plays a crucial role in monitoring a firm's risk profile and identifying areas to improve risk management. The object of internal auditing is to improve organizational efficiency and effectiveness through constructive criticism. Generally, internal audit has become an indispensable management tool for achieving effective control in both public and private organizations. In a study on a sample of Australian and New Zealand firms, Coram et al. (2008) established that organizations with an internal audit function are more likely to detect and self report fraud through misappropriation of assets than those that do not.

Performance auditing is described as engagements that provide assurance or conclusions based on an evaluation of sufficient, appropriate evidence against stated criteria, like specific requirements, measures or defined business practices (Morgan, 2009). It is further posited that control systems play a more vital role in private organizations due to their dynamic and complex environments, which may generate more risks for the firm. As such, internal auditing ought to be both important and effective in private than in public organizations. Importantly, it is averred that five standards for internal auditing include interdependence, professional proficiency, the scope of work, performance of the audit and management of the internal audit department (Cohen \& Sayag, 2010). It is asserted that auditors must comply with minimum continuing education requirements and professional standards published by their relevant professional organizations and the Institute of Internal Auditors (IIA, 2008). In the same light, Bou-Raad (2000) argued that auditors must have a high level 
of education in order to be considered a human resource. It is also noted that the diversity of skills required presents a huge challenge to professional bodies and management. According to IIA (2010), the purpose of auditing standards is to delineate basic principles that represent the practice of internal auditing; provide a framework for performing and promoting a broad range of value-added internal auditing; establish the basis for the evaluation of internal audit performance; and foster improved organizational processes and operations. In Nigeria, a study by Chukwunedu and Okoye (2011) indicated that risk based audit increases the ability of the auditor to detect fraud and as a result be able to assist in bridging the audit expectation in the country.

In Kenya a study by Kamau (2013) on the determinants of audit expectation gap indicated that there are certain factors that significantly affect the audit expectation gap. Kamau (2013) further posited that the main reason behind the audit practice it to capacitate the pertinent stakeholders to express an opinion whether or not the financial statements presented reflect a factual and fair picture. As such, the object of any audit is to ensure that financial records on which the auditor is reporting illustrate a true and fair view and are not misleading. According to Mose and Kuloba (2013) in the 2013 Kenya insurance industry outlook of the Insurance Regulatory Authority (IRA, 2013) noted that the insurance industry has established specialized departments which included amongst others, the internal audit department. This featured as a key success factor to the insurance sector against the backdrop of creation of specialized departments. Kenya Insurer (2012) notes that enterprise risk management (ERM) within Kenya Reinsurance is adequate for the risks it undertakes which reflect a limited investment risk appetite. In Kenya, the Government Financial Management Act, 2004, sets out the legal mandate for internal audit. In government ministries, a risk-based approach that includes participation by Ministry headquarters staff, has enabled appropriate allocation of limited staff to priority areas.

In her study on determinants of adoption of risk-based audit in Kenya's public, Lutta (2012) found that risk-based audit enhances transparency, accountability and responsiveness to public expenditure policy priorities. She further observed that, risk-based audit covers all aspects of financial management. Kiragu (2014) assessed challenges facing insurance companies in building competitive advantage in Kenya and established that the most significant factor in the light of the foregoing is the government regulation. From his deduction, the scholar recommended that insurance firms ought to be monitored based on their level of risk.

\section{Statement of the Problem}

A company's accounting control practices such as risk based auditing are widely believed to be crucial to the success of an enterprise as it acts as a powerful brake on the possible deviations from the predetermined objectives and policies. This means that an organization that puts in place an appropriate and adequate system of risk based auditing is likely to perform better than those that do not. In other words, for there to be effective risk management in an organization, auditing must be risk-based. In the instances where there have been lack of or inadequate risk-based auditing, the firms concerned may be prone to fraud and other forms of financial misappropriation (Coram et al. (2008). While much empirical works have given diverse reasons for the poor financial performance of insurance companies, research evidence on the effects of risk based auditing practices on the financial performance in the Kenyan context is scanty. Thus inadequate risk based audit could be negatively affecting the financial performance of insurance companies in Kenya. According to Hermanson and Rittenberg (2013) the existence of risk based auditing is associated with superior organizational performance. Although prior research studies (for example, Mak, 2009; Simons, 2009; Kiragu 2014) suggest a link between risk based audit practices and financial performance, majority of these studies have concentrated mostly in banks and other financial institutions and the available studies so far have dealt exclusively with large financial institutions in advanced countries. Little is known, at present, about the influences of risk based auditing practices on the financial performance of insurance companies not only nationally but also in Nakuru Town. It was in an attempt to fill this gap that this study sought to assess empirically the effects of risk assessment on the financial performance of insurance companies in Nakuru Town.

\section{Specific Objectives of the Study}

i. To determine the effect of risk assessment on financial performance of insurance companies in Nakuru town.

\section{Research Questions}

i. Does risk assessment influence financial performance of insurance companies in Nakuru town?

\section{Significance of the Study}

Risk based auditing is a very important element in financial performance. It is essential in both public and private sectors. Insurance companies like other organizations should be interested in how risk-based auditing affects their performance. The importance of this is based on the assertion that auditing based on risk assessment is bound to militate against risks. Thus the findings of the current study may assist the management 
of insurance firms in Kenya in understanding the importance of risk-based auditing in light of financial performance. This may assist them in decision making and formulating key financial strategies which can aid in mitigation of financial risks. The study may also be significant in that it may be a reference for other scholars interested in the field of insurance, audit, organizational financial performance and related areas.

\title{
Scope of the Study
}

The study was conducted among the internal auditors and the management staff in insurance companies in Nakuru town. It was carried out between August and September, 2014. The study was conducted within the budgetary allocation and time frame.

\section{Limitations of the Study}

The main limitation of study was inability to include more organizations as this study concentrated only on insurance companies due to resource constraints. The study would have covered more institutions across all sectors of the financial institutions so as to provide a more broad based analysis. However, the researcher recommended further studies in other financial institutions in Nakuru Town. The study also faced limitation of non corporation from the respondents especially where the management was unwilling to reveal information about the financial performance of the insurance companies and this sometimes delayed in filling of the questionnaire. The researcher made follow ups to ensure data was collected without further delays. The study also faced a limitation, whereby the respondents were found to be uncooperative because of the sensitivity of the information required for the study. The researcher explained to the respondents that the information they provided was to be held confidential and was going to be used for academic purpose only.

\section{Theoretical Review}

\section{Literature Review}

Various theories have been formulated to explain the pertinent issues influencing financial performance in organizations. This study was based on two theories namely the agency theory and the auditing theory.

\section{Agency Theory}

Agency theory attempts to describe the relationship between two parties where one party, the principal, delegates work to another party, the agent. As Eisenhardt (1989) noted, the theory of agency seeks to resolve problems in a relationship with conflict of interest and risk sharing when attitudes towards risk diverge. The economic variants of agency theory emphasize the costs and benefits of the principal-agent relationship. It is further observed that, while a beneficial agency cost is one that increases a shareholder's value, an unwanted agency cost may occur when the management actions conflict with the shareholder's interests. In the context of auditing, Hayes et al. (2005) asserts that agency theory holds that the auditor is appointed in the interests of both the third parties and also the management. On the other hand, the organization is viewed as a web of contracts. It is also posited that several groups which include among others, suppliers, bankers, customers, and employees, may make some sort of contribution to the company for a given price. The organization's management is tasked with coordinating these groups and contracts and try optimizing them for all parties concerned. This implies that purchased supplies are priced lowly, while the sold goods are priced highly. There are also low interest rates for loans, high share prices, and low wages for employees. In the relationships hitherto mentioned, the management is the "agent" that tries to gain contributions from "principals" such as bankers, shareholders, employees and others.

\begin{abstract}
Auditing Theory
Auditing theory helps to explain why auditing is needed in organizations. It also reveals certain laws that govern the audit process and its activities. Auditing theory enhances the understanding of the relationships and interrelationships between different parties of an organization. A sub-theory of auditing theory is the policeman theory. According to this theory, the auditor is responsible for searching, discovering and preventing fraud. Recently, the main focus of the auditors has been to provide reasonable assurance and verify the truth and fairness of the financial statements. The detection of fraud is, nevertheless, still a crucial topic in the debate on the auditor's responsibility, and typically after events where financial statement frauds have been revealed, the pressure increases the responsibilities of auditors in detecting fraud (Hayes et al., 2005).

The lending credibility theory is another sub-theory of auditing theory which postulates that the primary function of the audit is to add credibility to the financial statements. In light of the foregoing, the auditors are perceived to sell "credibility" to the clients. Audited financial statements are viewed as having elements that enhance the confidence of the financial users in the results presented by the management in the financial statements. On the other hand, the users are perceived to gain benefits from the increased credibility; these benefits are ideally considered to be that the quality of investment decisions improve when they are based
\end{abstract}


on reliable information (Ittonen, 2010).

Also as part of the audit theory is the "theory of inspired confidence" which Hayes et al. (2005) also regard as the "theory of rational expectations". The theory addresses both the demand and the supply for audit services. It is argued that the demand for audit services is a direct consequence of the participation of third parties in the organization. These parties demand for accountability from the management in return for their investments in the firm. In this light, accountability is realized through the issuance of periodic financial reports. It is, however, argued that the information provided by the management is probably biased, and as such outside parties have no direct means of monitoring. Auditing according to this theory risk based auditing is required to validate this information. It is emphasized that the auditor should always strive to meet the public expectations.

\section{Empirical Review on Risk Assessment}

Empirical studies on effect of risk assessment on financial performance are reviewed in this section. The studies are reviewed from the global, regional and local perspectives. Rostum and Eikebrokk (2008) conducted a study in Bergen, Norway on assessment of risk and came up with a report that provided a summary of the application and results of a Risk and Vulnerability Analysis (RVA). RVA was a as a response to the results from the internal and external evaluations. They followed a procedure of risk identification, risk estimation, and risk assessment; the latter creates an ample platform for risk management. According to McCord (2002), risk assessment of material misstatement at the financial statement level and also at the planning stage, clarifies the direction on performing a combined assessment of inherent and control risk, thus leaving the ability for the auditors to assess other risk factors in an audit. In their examination of the effects of the role of the board of directors in assisting in the formulation of corporate strategies on the auditors' planning judgments, they established that auditors respond to the role of the board when making judgments with respect to control risk assessments. Keitany (2000), in his study on the internal audit control function and its implication on risk assessment by external auditors, established that the extent of dependence on internal controls were insensitive to the strength of internal audit departments. A study on the impact of risk-based audit on financial performance in Kenya's insurance companies conducted by Kasiva (2012) among 44 respondents that included finance officers, internal auditors, credit officers, relationship officers, and accountants found out that risk-based auditing through risk management should be enhanced to enable the organization concerned to detect risks on time.

Kasiva (2012) further argues that fraud risk assessment is one area that deserves significant reliance on internal audit work. In this light, it is reasoned that due to the fact that internal auditors are more privy with the operations of the firm they work for than external auditors, are particularly suited to carry out fraud risk assessment. In a survey of internal auditors' risk management practices in the Kenya's banking sector, Kibaara (2007) investigated bank internal auditors' risk assessment practices and established that, most banks in Kenya were in the process of drafting the ERM process and strategies in line with risk assessment.

\section{Research Gaps}

Several studies (Keitany, 2000; Rostum \& Eikebrokk, 2008; Cohen and Sayag, 2010; Kasiva, 2012; Cummins, Scott \& Greg, 1994) have been carried out relative to the current study variables (risk assessment, risk-based planning, risk management internal auditing standards, and financial performance). However, it appears that there are very scanty if any studies that have been carried out in relation to how risk assessment, risk-based planning, risk management and internal auditing standards influence organizational financial performance in Kenya's insurance companies. This necessitated the current study which sought to bridge the aforementioned research gap.

\section{Methodology}

This study used descriptive survey design. Descriptive survey was preferred to other designs due to the fact that it enabled the study to capture the opinions of the respondents. More so, it enabled the researcher to answer "what?" as exemplified by the general research question: what is the effect of risk assessment on the financial performance? The population for this study constituted the staff drawn from internal audit departments and management of insurance companies registered by Insurance Regulatory Authority (IRA) in Nakuru Town. The accessible population of the study included 27 branch managers and 27 internal auditors or/and compliance managers. The target population was restricted to the scope of the study. There were 27 registered insurance companies operating in Nakuru town. Given that the target population is quite small, the researcher used the census survey whereby all members of the target population participated in the study. The census sampling was suitable not only due to the relatively small target population, but more importantly due to the fact that it gets rid of sampling bias which would otherwise occur if a scientific sampling procedure is conducted. The study used a structured questionnaire to collect data from the sampled respondents. The questionnaire primarily captured data pertinent to both the independent and dependent variables. The responses sought by the use of the questionnaire 
were based the extent to which the respondents agreed with the various indicators of the various variables of the study. A pilot study was conducted before carrying out the main study. The pilot study helped in the verification of both validity and reliability of the questionnaires. The study also used the Cronbach alpha $(\alpha)$ to test the reliability of the research instrument. Cronbach alpha $(\alpha)$ reliability coefficient above .78 was accepted for this study. In the current study, the object was to determine the content validity. Prior to collecting the required data, the researcher first sought permission to do so from the School of Human Resource Development of Jomo Kenyatta University of Agriculture and Technology. The consent of the branch managers of the insurance firms from which the sampled respondents were drawn was also sought. The questionnaires were administered by the researcher himself due to the fact that the insurance companies within the scope of the study were evenly distributed within Nakuru Town. The researcher collected the filled questionnaires after a period of time that was mutually agreed on between him and the respondents. The filled questionnaires were first screened to ensure that only the adequately and appropriately filled ones were considered in data processing and analysis. The data was coded and entered into the computer before being analyzed by the aid of the Statistical Package for Social Sciences (SPSS) software. Descriptive (mean and standard deviation) and inferential analysis (Pearson's correlation) were used to analyse data and the findings presented in tables that reflected both descriptive and inferential statistics.

\section{Results And Discussion}

Risk Based Audit in Insurance Companies in Nakuru Town

The study sought to ascertain whether there were risk based audit in insurance companies in Nakuru Town. This was done by asking the respondents to respond to the dimensions of risk based audit and the results obtained are presented in table 1 .

Table 1: Influence of Risk Based Audit on Financial Performance

\begin{tabular}{lcccccccc}
\hline Indicators of Risk Based Audit & SD & D & N & A & SA & N & Mean & SDev \\
\hline Risk Assessment & 3 & 3 & 14 & 10 & 22 & $\mathbf{5 2}$ & 3.51 & 0.39 \\
Audit plans with the management & 2 & 3 & 5 & 19 & 23 & $\mathbf{5 2}$ & 3.98 & 0.64 \\
Risk Management & 3 & 5 & 7 & 7 & 30 & $\mathbf{5 2}$ & 3.77 & 0.53 \\
Audit standards reporting & 4 & 4 & 6 & 18 & 20 & $\mathbf{5 2}$ & 3.88 & 0.64 \\
\hline
\end{tabular}

Source: Research Data (2014)

From the findings it is evident that majority of the respondents indicated that audit plans had the highest influence on financial performance in insurance companies as indicated by a mean of 3.98 with a standard deviation of 0.64. This was followed by audit standard reporting which had a mean of 3.88 with a standard deviation of 0.64 . The study also found out that risk management affects financial performance as indicated by a mean of 3.77 with a standard deviation of 0.53 . The study further found that assessment of risks also had a high effect on financial performance as indicated by a mean of 3.51 with a standard deviation of 0.39 . This implies that the implementation of risk based auditing in insurance companies is expected to improve financial performance, transparency, accountability and efficiency in the management of insurance companies' affairs making it more effective in the delivery of best services to its clients. This finding are in agreement with the results of a study done by the Kiragu (2014) which found out that risk based audit implementation may also deepen the facilitation of private sector participation in the economy by encouraging investments, job creation and development of business initiatives to reduce poverty.

\section{Presence of Risk Assessment in Insurance Companies in Nakuru Town}

The researcher sought to establish from the respondents whether there was risk assessment in insurance companies and whether the risk assessment influenced financial performance in the insurance companies in Nakuru Town. The results are presented in the table 2.

Table 2: Presence of Risk Assessment

\begin{tabular}{lcc}
\hline Response & Frequency & Percentage (\%) \\
\hline YES & 38 & 74 \\
NO & 14 & 26 \\
\hline Total & $\mathbf{5 2}$ & $\mathbf{1 0 0}$ \\
\hline
\end{tabular}

Source: Research Data (2014)

From the findings, $74 \%$ of the respondents indicated that there was risk assessment in insurance companies in Nakuru Town compared to $26 \%$ who indicated that risk assessment did not exist in insurance companies in Nakuru Town. Based on the higher percentage of the respondents indicating presence of risk based 
assessment it can be observed that insurance companies in Nakuru town conducted risk assessment; thus risk assessment affected financial performance in insurance companies in Nakuru Town.

\section{Effects of Risk Assessment on Financial Performance in Insurance Companies}

The study sought to ascertain the extent to which different indicators of risk assessment influenced financial performance in insurance companies in Nakuru Town. The respondents were asked to respond to selected indicators based on the extent to which they felt the indicators had effects on financial performance. The levels of measurements were Strongly Disagree, Disagree, Neutral, Agree and Strongly Agree. The findings obtained are presented in table 3 .

Table 3: Effects of Risk Assessment on Financial Performance

\begin{tabular}{|c|c|c|c|c|c|c|c|c|}
\hline Statement & SD & $\mathbf{D}$ & $\mathbf{N}$ & $\mathbf{A}$ & SA & $\mathbf{N}$ & Mean & SD \\
\hline Consideration of risk assessment in error detection & 4 & 4 & 10 & 9 & 25 & 52 & 3.77 & 0.73 \\
\hline Auditors understand insurance companies' risk & 8 & 7 & 13 & 4 & 20 & 52 & 3.89 & 0.83 \\
\hline Easy to assess risks at the insurance companies & 2 & 2 & 10 & 9 & 29 & 52 & 3.97 & 0.77 \\
\hline Auditor's involvement in risk evaluation process & 8 & 3 & 2 & 17 & 22 & 52 & 4.33 & 0.41 \\
\hline Auditors identify changes in financial performance & 8 & 4 & 30 & 1 & 13 & 52 & 3.21 & 0.23 \\
\hline
\end{tabular}

\section{Source: Research Data (2014)}

Results in table 3 shows that consideration of risk assessment in error detection, the auditors understanding of the insurance companies risk disposition and the ease with which to assess risk had higher influence on financial performance in insurance companies in Nakuru Town as indicated by a mean of 3.97, 3.89 and 3.77 with a standard deviation of $0.77,0.83$ and 0.73 respectively. The results also show that the auditors recognition of their work in risk assessment, auditor's involvement of management in risk evaluation process and auditors identification of changes that may influence financial performance in their company affected financial performance in insurance companies in Nakuru Town to a great extent as indicted by a mean of 3.57, 3.43 and 3.21 with a standard deviation of $0.67,0.41$ and 0.23 respectively. This clearly indicates that risk assessment affected the financial performance in insurance companies in Nakuru Town.

\section{Factors Influencing Risk Assessment in Insurance Companies}

The study also sought to establish whether challenges within the process of risk assessment could affect the internal auditors in carrying out risk assessment. The levels of measurements were Strongly Disagree, Disagree, Neutral, Agree and Strongly Agree. The findings obtained are presented in table 4.

Table 4: Factors Influencing Risk Assessment in Insurance Companies

\begin{tabular}{lccccccrr}
\hline Statement & SD & D & N & A & SA & N & Mean & \\
& & & & & & & \\
SD & 12 & 2 & 8 & 13 & 17 & $\mathbf{5 2}$ & 3.81 & 0.76 \\
Lack of adequate funds & 4 & 9 & 17 & 11 & 11 & $\mathbf{5 2}$ & 3.54 & 0.53 \\
The complexity of operations & 14 & 8 & 10 & 2 & 18 & $\mathbf{5 2}$ & 3.53 & 0.42 \\
The quality of personnel in internal audit & 12 & 4 & 10 & 6 & 20 & $\mathbf{5 2}$ & 3.74 & 0.79 \\
\hline
\end{tabular}

Source: Research Data (2014)

The respondents were required to indicate the extent to which the selected factors were significant in influencing risk assessment in insurance companies in Nakuru Town. From the findings, majority of the respondents indicated that effective controls and quality of personnel in internal audit as indicators of risk assessment were very significant in influencing risk assessment in insurance companies in Nakuru Town as indicated by a mean of 3.81 and 3.74 with standard deviation of 0.76 and 0.79 . The study further found that most of the respondents indicated that lack of adequate funds and the complexity of operations had high significance in influencing judgments of risk in insurance companies as indicated by a mean of 3.54 and 3.53 with standard deviation of 0.53 and 0.42 . This implied that the management needs to bear the responsibility for managing risks. This is in agreement with a previous study by Al-Tamimi, (2002) who found that many risks are very significant to the organization and the discussion of their controls will involve more senior managers and directors than might be involved in traditional finance oriented audits.

\section{Correlation Analysis}

Pearson' correlation analysis was applied to test the relationship between risk based audit and financial performance in insurance companies in Nakuru Town. This section presents results established. The dimension of risk based auditing tested was risk assessment (RA) while financial performance (FP) was measured using 
profitability, sales volume and market share. The relationship was established through Pearson correlation analysis as presented in table 5 .

Table 5: Pearson's Correlation Analysis

\begin{tabular}{|c|c|c|}
\hline & $\begin{array}{l}\text { Risk Assessment(RA) } \\
\text { Total Score }\end{array}$ & $\begin{array}{c}\text { Financial Performance (FP) } \\
\text { Total Score }\end{array}$ \\
\hline $\begin{array}{ll}\text { RA. Total Score } & \text { Pearson Correlation } \\
& \text { Sig. }(2 \text { tailed }) \\
\text { Total Score } & \text { N }\end{array}$ & $\begin{array}{c}1 \\
52\end{array}$ & $\begin{array}{l}0.494^{*} \\
.000 \\
52\end{array}$ \\
\hline $\begin{array}{cc}\text { FP Total Score } & \text { Pearson Correlation } \\
& \text { Sig. }(2 \text { tailed }) \\
& \text { N }\end{array}$ & $\begin{array}{c}0.494^{*} \\
.000 \\
52\end{array}$ & $\begin{array}{l}1 \\
52\end{array}$ \\
\hline
\end{tabular}

$* \sigma=0.01$ (Correlation is significant at 0.01 level (2-tailed)

\section{Source: Research Data (2014)}

The correlation table presents the relationship between risk assessment and financial performance. It is evident that risk assessment has a positive moderate relationship with financial performance $(r=0.494, p<$ 0.01). This suggests that risk assessment relates positively with financial performance in insurance companies in Nakuru town. The findings are similar to that of Maiteka (2010) who found that there existed a strong and positive relationship between risk assessment and corporate governance in public sectors.

\section{Conclusion}

Based on the findings of the study it is concluded that risk assessment exists in insurance companies in Nakuru Town. Risk assessment can help detect risks and enhance financial performance in insurance companies. Risk assessment helps to minimize risk, increases transparency and accountability hence enhancing financial performance in insurance companies in Nakuru Town. Internal auditors' understanding of the insurance companies' risk, consideration of risk assessment in the detection of errors, auditor`s recognition of work environment in risk assessment and management, auditor's involvement of management in risk evaluation process and auditors identification of changes that influence insurance companies are the indicators of risk assessment which influences financial performance in insurance companies in Nakuru Town. Finally the study concluded that there exists a positive moderate relationship between risk assessment and financial performance in insurance companies in Nakuru Town.

\section{Recommendations}

Based on the conclusion, the study recommends that risk based audit should be enhanced through adoption of better risk assessment practices so as to achieve success in financial performance in insurance companies in Nakuru Town. The study further recommends that the management of insurance companies in Nakuru Town should emphasize on auditors understanding of the risk based audit in order to enhance detection and control of risks in insurance companies. From the findings, the study recommends that the management of insurance companies in Nakuru Town should bear the responsibility in defining effective implementation of audit recommendation, risk based audit plans, timely reception of risk based audit reports and allocation of adequate resources for risk based audit. This would enhance transparency and accountability through improved efficiency, accuracy, completeness, timeliness, convenience and clarity in general performance of insurance companies in Nakuru Town. It is further concluded that the management of insurance companies in Nakuru Town should adopt effective risk based audit practices such as risk assessment in order to enhance effective and efficient financial performance in the insurance companies in Nakuru Town.

\section{Suggestions For Further Studies}

The study determined the effects of risk-based audit on financial performance in insurance companies in Nakuru Town. The study recommends that a further study should be carried out to investigate the challenges facing risk-based audit in insurance companies. A further study on the effects of risk-based audit on financial performance in commercial banks in Nakuru Town is suggested. The study also suggests that a further study be undertaken to establish the challenges affecting implementation of risk based audit in insurance companies in other counties in Kenya as a way of enhancing generalizability of the results. Finally the study recommends a further research to determine the effects of risk-based audit in other financial institutions particularly on Saving Credit cooperative societies registered in Kenya. This would lead to revealing the effects of risk based audit practices on financial performance in such institutions in Kenya. 


\section{Acknowledgement}

I wish to express my sincere appreciation to all the people who ensured the successful completion of this report. It is not possible to list all of them here but I have immensely appreciated their contribution. First and most importantly I thank the Almighty God for the gift of life and for granting me the opportunity to conduct this study. I also wish to wish to extend my sincere gratitude to my supervisors Mr. Solomon Ngahu and Mr. Juma Wagoki who made several helpful recommendations on my final manuscript critical. All my lecturers also deserve a special mention for the useful guidance and discussions that helped to shape my topic especially during the defense. I also wish to extend my sincere appreciation to all my classmates. I particularly wish to thank my close friend John Wakiriba for his encouragement and for supporting me throughout the research process. Without them, and especially those from my faculty, the program would have been an uphill task. Lastly, I must thank Esther Mungai for typing the manuscript and meeting the strict deadline without complaining. To all of you, may our good Lord bless you mightily.

\section{References}

[1]. Al-Tamimi, H, (2002). Risk Management Practices: An Empirical Analysis of the UAE Commercial Microfinance Institutions, Finance India, 16(3), 1045-1057.

[2]. Association of Kenya Insurers (2012). The Kenya insurer. Journal of the association of Kenya insurers.

[3]. Beekes, W., \& Brown, P. (2006). Do better governed Australian firms make more informative disclosures, Journal of Business Finance \& Accounting, 33(3-4), 422-50.

[4]. Chekwunedu, B. \& Okoye, O. (2011). Internal Audit Problems and possible Solutions CMD Workshop on Auditing in Private and Public Sector Organizations. Nigerian Management Review 7 (I) 6-11.

[5]. Cohen, A., \& Sayag, G. (2010). The effectiveness of internal auditing: an empirical examination of its determinants in Israeli organizations. Australian Accounting Review, 54(20), 296-307.

[6]. Coram, P. \& Woodliff, D. (2004). The effect of risk of misstatement on the propensity to commit reduced quality acts under time budget pressure. Auditing: A Journal of Practice \& Theory, 23 (2): 159-167.

[7]. Eisenhardt, K. (1989). Control: Organizational and economic approaches. Management Science, 31(2)134-149.

[8]. Goodwin-Stewart, J. \& Kent, P. (2006). The Use of Internal Audit by Australian Companies. Managerial Auditing Journal, 21, 81101.

[9]. Hayles, R. (2005). Principles of Auditing, New York: Pearson Education Limited.

[10]. Hermanson, D. R. \& Rittenberg, L. (2013). Internal Audit and Organizational Governance. Florida. The Institute of Internal Auditors Research Foundation.

[11]. Institute of Internal Auditors (2008). International standards for the professional practice of internal auditing standards. Almonte Springs FL, USA: The Institute of Internal Auditors.

[12]. Institute of Internal Auditors (2010). International standards for the professional practice of internal auditing standards. Almonte Springs FL, USA: The Institute of Internal Auditors.

[13]. Ittonen, K. (2010). A theoretical examination of the role of auditing and the relevance of audit Reports

[14]. Kamau, C. G. (2013). Determinants of audit expectation gap: Evidence from limited companies in Nakuru Town. International Journal of Science and Research (IJSR), 2(1), 480-491

[15]. Kasiva, M. V. (2010). The impact of risk based audit on financial performance in insurance companies in Nairobi. MBA thesis, University of Nairobi.

[16]. Keitany, J. L. (2000). The Internal Audit control function and its implication for risk assessment by the external auditor: A case of quoted companies. Unpublished MBA Project, University of Nairobi.

[17]. Kibaara, C. W. (2007). A survey of internal auditors' risk management practices in the banking industry in Kenya. Unpublished MBA Project, University of Nairobi.

[18]. Kiragu, S. M. (2014). Assessment of Challenges facing insurance companies in building competitive advantage in Kenya. International journal of social sciences and entrepreneurship, 1(11)469-490.

[19]. Maiteka, S. (2010). The Influence of Risk Based Audit on Corporate Governance In Public Sector In Kenya Focusing on Selected Ministries.

[20]. McCord, C. (2002). The assessment: Corporate governance and Risk based Audit practices. Oxford Review of Economic Policy, 8(3), 23-41.

[21]. Morgan, S. L. (2009). Risk based performance audit project planning. Guam: APIPA.

[22]. Rittenberg, L. E. \& Schwieger, B. J. (1997). Auditing: Concepts for a Changing Environment, New York: The Dryden Press.

[23]. Rostum, J., \& Eikebrokk, B. (2008). Risk assessment case study - Bergen, Norway. Techneau, 4, 1-21.

[24]. Sarens, G. \& de Beelde, I. (2006). Internal auditors' perception about their role in Corporate Governance: a comparison between US and Belgian companies. Managerial Auditing Journal, 21(1)63-68

[25]. Simmons, M. R. (1997). COSO Based Auditing. 